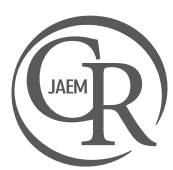

\section{Traumatic Aortic Intramural Hematoma}

\author{
Travmaya Bağlı Intramural Aort Hematomu
}

\author{
Mehmet Özgür Erdoğan', Emine Gaffari', Ahmet Şenel', Türker Karaboğa', Seçil Telli Erdoğan² \\ 'Department of Emergency Medicine, Haydarpaşa Numune Training and Research Hospital, İstanbul, Turkey \\ 2Department of Radiology, Haydarpaşa Numune Training and Research Hospital, İstanbul, Turkey
}

\begin{abstract}
Blunt traumatic aortic injury is a life threatening condition with a mortality rate of $30 \%$. Aortic injury commonly involves the thoracic aorta with pseudoaneurysm and intramural hematoma. Aortic intramural hematoma is a dissection without an intimal tear. Intramural aortic hematoma is an uncommon but potentially lethal aortic disease. TEE, CT, MRI and Multidetector CT can ensure a rapid and accurate diagnosis of intramural hematoma. Management of traumatic aortic intramural hematoma is not well defined in the literature. Significant intramural aortic hematoma in stable patients may remain stable on follow-up imaging. In this study we present a traumatic aortic intramural hematoma which resolved with conservative treatment in a 36 year old man who fell from a height.
\end{abstract}

Keywords: Trauma, aorta, hematoma

Received: 07.02.2012 Accepted: 24.02.2012

\section{ÖZET}

Travmaya bağlı aort hasarı nadir görülür ve yaklaşık \%30 mortalite ile seyreder. Sıklıkla torasik aortada psödoanevrizma ve intramural hematom gözlenir. İntramural hematom, intimal yırtılma olmaksızın aort disseksiyonu olarak tanımlanmıştır. İntramural aort hematomu oldukça nadir görülen, ölümcül potansiyele sahip bir durumdur. TEE, BT, MRG ve multidetector BT kullanılarak hızlı ve güvenilir şekilde tanıya varılabilir. Travmatik intramural aort hematomunun yönetimi literatürde yeterince tanımlanmamıştır. Görüntüleme yöntemlerinin gelişmesi sayesinde nonkomplike, stabil hastalarda intramural aort hematomu konservatif yöntemle tedavi edilebilir. Bu makalede konservatif yöntemle tedavi edilen travmatik intramural aort hematomu olan 36 yaşındaki yüksekten düşme hastası sunulmuştur.

Anahtar Kelimeler: Travma, aort, hematom Geliş Tarihi: 07.02.2012 Kabul Tarihi: 24.02.2012

\section{Introduction}

Traumatic aortic intramural hematome $(\mathrm{AlH})$ is a life threatening condition, with a mortality rate of 30\% (1). Intramural hematome or pseudoaneurysms are generally observed in the thoracic aorta $(2,3)$. AlH was first described by Krukenberg as an aortic dissection without initial rupture of the intima (4). Aortic intramural hematoma can appear in atherosclerotic hypertensive patients who have an hemorrhage from a vasa vasorum rupture into the media, as a result of penetrating atherosclerotic ulcers (5). Rarely, thoracic traumas may lead to aortic intramural hematoma $(6,7)$. The aim of this study was to present the procedures of diagnosis and treatment in this rare aortic disease.

\section{Case Report}

A thirty-six year old male was transferred to our emergency service following a suicidal fall from the sixth floor. The patient fell 20 minutes prior to admisson to the emergency service. He had no history of known medical illness or medication. On arrival, the patient's Glasgow Coma Scale score was E1M1V1 and paramedics were assisting his ventilation. Physical examination of the patient revealed an arterial blood pressure of $90 / 60 \mathrm{mmHg}$ and pulse rate of $110 \mathrm{beats} / \mathrm{min}$. His breath sounds were asymmetric and markedly decreased in the right hemithorax. Multi detector computerized tomography (MDCT) scans revealed a subarachnoid haemorrhage, right diaphragmatic rupture, grade 4 hepatic laceration, first and second rib fractures, AlH on the proximal part of the descending aorta, right hemothorax and free fluid in the abdomen (Figure 1, 2).

The patient was intubated on admission to our emergency service. A chest tube was inserted for the right hemothorax (Figure 3). No medication for AlH was administered due to hypotension. AlH treatment was planned after cardivascular surgery consulta- 

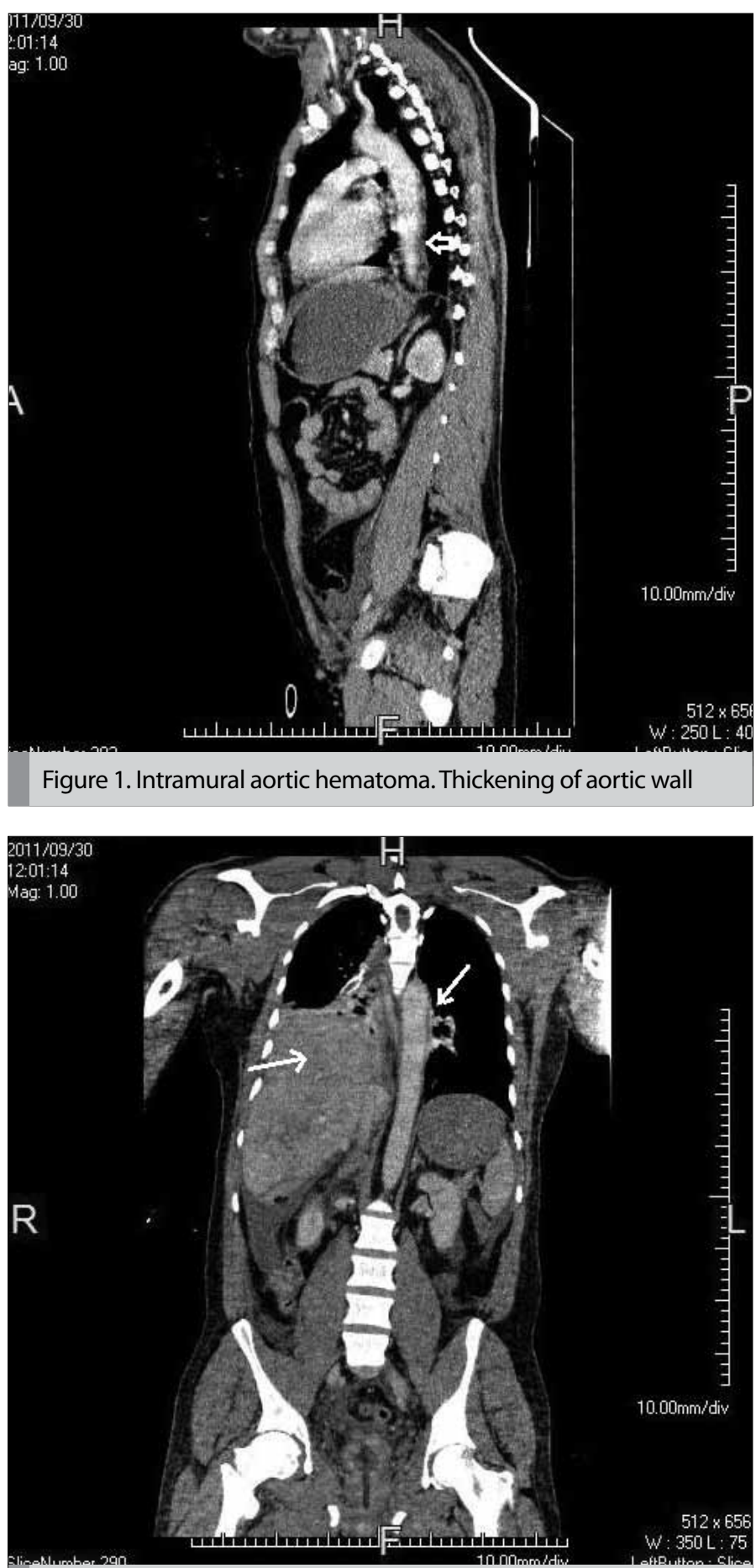

Figure 2. Thickening of aortic wall and diaphragmatic rupture

tion. Open surgical repair of the diaphragmatic rupture and hepatic laceration was performed by general surgery. The patient was hospitalized in the intensive care unit (ICU) after surgery. Metoprolol 15 $\mathrm{mg} /$ day was administered after hemodynamic ressucitation of the patient. On day 15. of ICU hospitalization MDCT revealed that the AlH was resorbed. On the $80^{\text {th }}$. day of ICU hospitalization; the patient was transferred to the surgery clinic and discharged from hospital 3 days later.

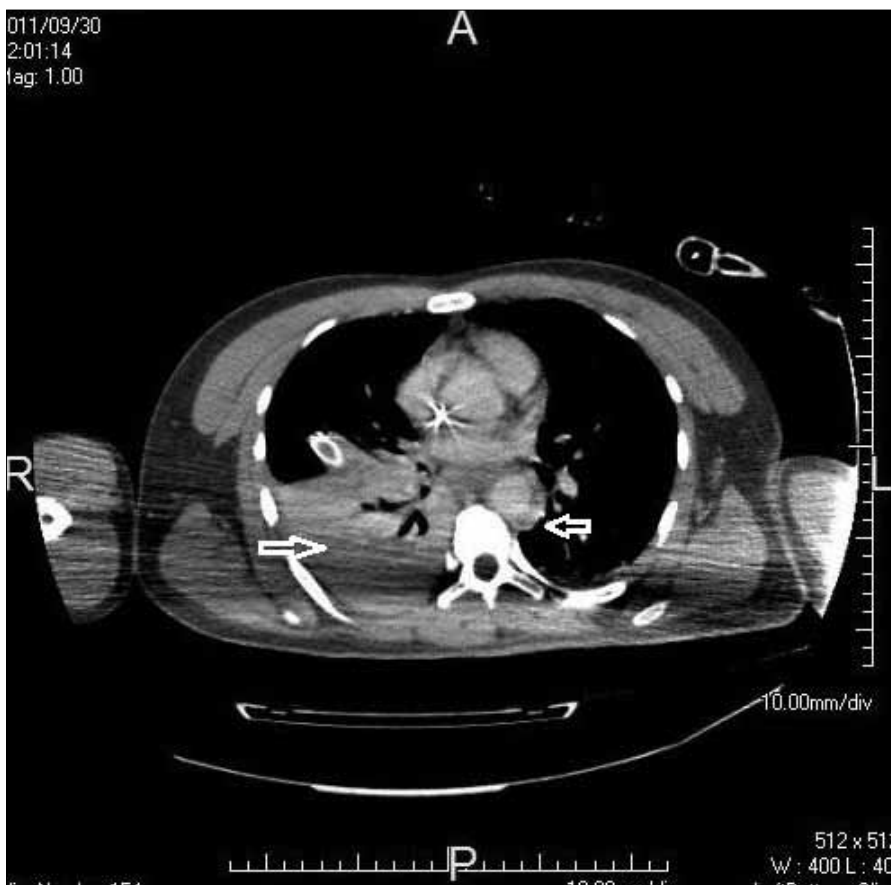

Figure 3. Chest tube, right hemothorax and thickening of aortic wall

\section{Discussion}

Thoracic traumatic AlH is a rare condition with high mortality $(1,6,7)$. AlH is divided into subtypes A and B (5). Generally, type A leads to dissection and rupture complications. Surgical treatment is generally preferred for type A AlH $(8,9)$. Type B is $50-85 \%$ of all AlHs and is common in hypertensive patients (9).

Chest and back pain is a frequent clinical manifestation in $\mathrm{AlH}(2,8)$. Chest pain is more common with ascending (proximal type A) $\mathrm{AlH}$. Upper or lower back pain occurs with descending (distal-type B) lesions $(2,9)$. Transesophageal echocardiography (TEE), CT, magnetic resonance imaging (MRI) and MDCT may accurately reveal the $\mathrm{AlH}$ $(9,10)$. Widening of the mediastinum or the aortic shadow, pleural effusion, crescent shaped pseudo-lumen, dislocation of intimal calcification may be illustrated on CT images (11-13). Thorax CT is approximately $100 \%$ sensitive in $\mathrm{AlH}$ (13). AlH was diagnosed with MDCT in our case. AlH may only be excluded with CT scanning in unconscious trauma patients.

Aortic intramural hematoma is considered as a dissection progress, and could be considered as a precursor of aortic dissection, pericardial tamponade and rupture (5). Surgical repair has to be preferred in type A AlH due to the high complication rates. Medical treatment may be the treatment of choice in uncomplicated type B (descending aorta) AlH (4). With the development of imaging techniques, uncomplicated stable patients with aortic intramural hematoma have the opportunity of receiving conservative treatment $(2,14-17)$. Detailed diagnostic confirmation of $\mathrm{AlH}$ supported the decision of conservative treatment in our case.

Mortality may be reduced by early diagnosis and treatment in $\mathrm{AlH}(6,7)$. It is obvious that emergency services are the point of admission 
to hospital for $\mathrm{AlH}$ patients. AlH, especially in high-energy trauma should be considered as a preliminary diagnosis by the emergency physician. Surgical and medical procedures are used together in traumatic AlH treatment (15). AlH patients with acute cardiac tamponade or aortic rupture, stubborn subacute or acute pain, progress in the type A dissection, aneurysm rupture, aneurysmal dilatation of $60 \mathrm{~mm}$ and above should undergo surgical treatment (18). The above mentioned complications were not observed and there was no need for surgical treatment in our case. Aladham et al found 31\% $\mathrm{AlH}$, in a case series of traumatic aortic injury (2). They showed that injury was localized at the isthmus, diaphragmatic hiatus and abdominal aortic regions (2). Traumatic AlH resorbs faster than spontaneous AlH. Minor uncomplicated AlH may be treated conservatively with blood pressure regulation and serial CT follow-up (2, 9, 14-16). Intravenous antihypertensive agents such as nitrates, calcium channel blockers and beta blockers to keep the level of systolic blood pressure between 100-130 mmHg are recommended (11, 17, 18). Beta blockers protect by reducing the arterial pressure and stress on the aortic wall. Our patient was hypotensive on admission due to the hemothorax and hepatic laceration. Blood pressure was in the normal range during ICU hospitalization. During ICU hospitalization, metoprolol $15 \mathrm{mg} /$ day was administered through the intravenous route. In a hypertensive $\mathrm{AlH}$ patient, antihypertensive agents must be urgently administered. Conservative treatment was satisfactory in our case and substantial CT imaging revealed that AlH was resorbed completely.

\section{Conclusion}

Traumatic AlH is a rare, life,threatening disease. Chest pain is more common with ascending (type A) AlH. Upper or lower back pain occurs with descending (type B) lesions. Especially blunt trauma patients with these complaints should be considered as $\mathrm{AlH}$ in the emergency department until $\mathrm{AlH}$ is excluded with diagnostic imaging.

\section{Conflict of interest}

No conflict of interest was declared by the authors.

\section{References}

1. Fabian TC, Richardson JD, Croce MA, Smith JS Jr, Rodman G Jr, Kearney PA, et al. Prospective study of blunt aortic injury: Multicenter Trial of the American Association for the Surgery of Trauma. J Trauma 1997; 42: 374-803. [CrossRef]

2. Aladham F, Sundaram B, Williams DM, Quint LE. Traumatic aortic injury: computerized tomographic findings at presentation and after conservative therapy. J Comput Assist Tomogr 2010; 34: 388-94. [CrossRef]
3. Kocoogullari CU, Emmiler M, Saglam H, Yavuz Y, Yurumez Y, Cekirdekci A. Infrarenal Abdominal Aortic Pseudoaneurysm in a Case with Abdominal Aortic Atheromatous Plaque after Blunt Trauma: A Case Report and Review of the Literature. JAEM 2009; 8: 56-9.

4. Krukenberg E. Beitrage zur Frage des Aneurysma dissecans. Beitr Pathol Anat Allg Pathol 1920; 67: 329-51.

5. Baikoussis NG, Apostolakis EE, Siminelakis SN, Papadopoulos GS, Goudevenos J. Intramural haematoma of the thoracic aorta: who's to be alerted the cardiologist or the cardiac surgeon? J Cardiothorac Surg 2009; 4: 54. [CrossRef]

6. Larson EW, Edwards WD. Risk factors for aortic dissection: a necropsy study of 161 cases. Am J Cardiol 1984; 53: 849-55. [CrossRef]

7. Reed D, Reed C, Stemmermann G, Hayashi T. Are aortic aneurysms caused by atherosclerosis? Circulation 1992; 85: 205-11. [CrossRef]

8. Vilacosta I, San Román JA, Ferreirós J, Aragoncillo P, Méndez R, Castillo $J A$, et al. Natural history and serial morphology of aortic intramural hematoma: a novel variant of aortic dissection. Am Heart J 1997; 134: 495507. [CrossRef]

9. Nienaber CA, von Kodolitsch Y, Petersen B, Loose R, Helmchen U, Haverich $A$, et al. Intramural hemorrhage of the thoracic aorta. Diagnostic and therapeutic implications. Circulation 1995; 92: 1465-72. [CrossRef]

10. Saritas A, Günes H, Kandis H, Cıkman M, Candar M, Korkut S, et al. A Retrospectice Analysis of Patients Admitted to our Clinic with Aortic Dissection. JAEM 2011; 10: 152-5.

11. Ledbetter S, Stuk JL, Kaufman JA. Helical (spiral) CT in the evaluation of emergent thoracic aortic syndromes. Traumatic aortic rupture, aortic aneurysm, aortic dissection, intramural hematoma, and penetrating atherosclerotic ulcer. Radiol Clin North Am 1999; 37: 575-89. [CrossRef]

12. Yüksel A, Erdur B, Türkçüer İ, Aydın B, Canbora PT. Acil Serviste Rüptüre Olmamış Aort Anevrizma ve Diseksiyonlarının Değerlendirilmesi: Olgu Serisi. JAEM 2008; 2: 17-20.

13. Yamada T, Shimpei T, Harada J. Aortic dissection without intimal rupture: diagnosis with MR imaging and CT. Radiology 1988; 2: 347-52.

14. Fabian TC, Davis KA, Gavant ML, Croce MA, Melton SM, Patton JH Jr, et al. Prospective study of blunt aortic injury: helical $C T$ is diagnostic and antihypertensive therapy reduces rupture. Ann Surg 1998; 227: 666-77. [CrossRef]

15. Hirose H, Gill IS, Malangoni MA. Nonoperative management of traumatic aortic injury. J Trauma 2006; 60: 597-601. [CrossRef]

16. Holmes JH 4th, Bloch RD, Hall RA, Carter YM, Karmy-Jones RC. Natural history of traumatic rupture of the thoracic aorta managed nonoperatively: a longitudinal analysis. Ann Thorac Surg 2002; 73: 1149-54. [CrossRef]

17. Kepros J, Angood P, Jaffe CC, Rabinovici R. Aortic intimal injuries from blunt trauma: resolution profile in nonoperative management. J Trauma 2002; 52: 475-8. [CrossRef]

18. Motoyoshi N, Moizumi Y, Komatsu T, Tabayashi K. Intramural hematoma and dissection involving ascending aorta: the clinical features and prognosis. Eur J Cardiothorac Surg 2003; 24: 237-42. [CrossRef] 